\title{
The Influence of Incorporation of Octadecenoic Acid on the Cell-associated Fructosyltransferase and the Extracellular Glucosyltransferase Activities of Streptococcus salivarius
}

\author{
By LYNDA J. PITTY (Née MARKEVICS) ANd NICHOLAS A. JACQUES* \\ Institute of Dental Research, United Dental Hospital of Sydney, Surry Hills, \\ New South Wales 2010, Australia
}

(Received 1 April 1987; revised 28 July 1987)

\begin{abstract}
The rate of expression of the cell-associated fructosyltransferase $\left(\mathrm{FTF}_{\mathrm{m}}\right)$ activity of Streptococcus salivarius ATCC 25975 grown in continuous culture was linearly related to the rate of octadecenoic acid $\left(\mathrm{C}_{18: 1}\right)$ incorporation into the membrane lipids irrespective of the presence or absence of Tween 80 in the growth medium. This observation was confirmed with data obtained from cells grown in the presence of a series of n-alkanols. The results suggested that cosynthesis of lipids containing $C_{18: 1}$ residues was necessary for $F_{T F}$ expression and accounted for the slight stimulation of enzyme expression by Tween 80 at all growth rates. In contrast, addition of Tween 80 to the growth medium resulted in several-fold increases in extracellular glucosyltransferase $\left(\mathrm{GTF}_{\mathrm{e}}\right)$ production irrespective of the growth rate. Following the addition of the surfactant to the growth medium, an exponential relation between the increased rate of $\mathrm{GTF}_{\mathrm{e}}$ production and the concomitant net increase in the rate of $\mathrm{C}_{18: 1}$ incorporation was noted. The results obtained in continuous culture emphasized the underlying effect growth rate had on $\mathrm{GTF}_{\mathrm{e}}$ production, especially when Tween 80 was added to the growth medium. In the presence of n-alkanols, the rate of $\mathrm{GTF}_{\mathrm{e}}$ production plotted as a single ' $U$ '-shaped curve with respect to the rate of $\mathrm{C}_{18: 1}$ incorporation irrespective of the chain length of the n-alkanol studied. Rapid analyses of the extracellular proteins by SDS-PAGE suggested that hexan-1-ol and Tween 80 specifically stimulated the synthesis and secretion of $\mathrm{GTF}_{\mathrm{e}}$ and no other extracellular protein. The combined results emphasized the dissimilarity between amphiphilic modulation of FTF $_{m}$ and $\mathrm{GTF}_{\mathrm{e}}$ production as well as the apparent unique stimulation of the synthesis and secretion of the latter enzyme(s).
\end{abstract}

\section{INTRODUCTION}

A number of observations have led us to believe that the lipid composition is an important parameter in controlling the expression of glycosyltransferases in Streptococcus salivarius. In particular, the apparent co-ordinated synthesis and secretion of glucosyltransferase activity $\left(G_{T} F_{e}\right)$ can be enhanced by a variety of amphiphilic compounds including Tween 80 (polyoxyethylene sorbitan mono-oleate) (Wittenberger et al., 1978; Jacques et al., 1985), octyl $\beta$ D-glucopyranoside (Jacques, 1985) and hexan-1-ol (Markevics et al., 1987) or by changing the environmental concentration of $\mathrm{K}^{+}$(Markevics \& Jacques, 1985). While all of these conditions give rise to an adaptive change in the fatty acid composition of the membrane lipids, particularly the $\mathrm{C}_{18}$-fatty acids, there appears to be no consensus as to the direction or degree of change that occurs within the fatty acids of the membrane lipids leading to enhanced $\mathrm{GTF}_{\mathrm{e}}$ expression. In contrast, all available data indicate that cell-associated fructosyltransferase $\left(\mathrm{FTF}_{\mathrm{m}}\right)$ activity decreases with an increase in saturation of the membrane lipids (Jacques, 1985; Markevics $e t$ al., 1987).

\footnotetext{
Abbreviations: $\mathrm{GTF}_{\mathrm{e}}$, extracellular glucosyltransferase; $\mathrm{FTF}_{\mathrm{m}}$, cell-associated fructosyltransferase; $\mathrm{FTF}_{\mathrm{e}}$, extracellular fructosyltransferase; $U / S$ ratio, ratio of unsaturated to saturated fatty acids.
} 
In the present communication we have analysed the rates of incorporation of octadecenoic acid in continuous culture in the presence or absence of Tween 80 . The results have led us to propose that the expression of $\mathrm{FTF}_{\mathrm{m}}$ activity is dependent upon the rate of incorporation of octadecenoic acid $\left(\mathrm{C}_{18: 1}\right)$ into the cell membrane while reaffirming that the enhancement of $\mathrm{GTF}_{\mathrm{e}}$ expression is far more complex.

\section{METHODS}

Organism, media and growth conditions. S. salivarius ATCC 25975 was used throughout these studies. All batch cultures were of $11 \mathrm{ml}$ volume and were grown to late exponential-early stationary phase in semi-defined medium (Jacques, 1983) containing $1 \mathrm{~mm}-\mathrm{CaCl}_{2}$. Glucose (25 mM) served as the fermentable carbon source. Continuous culture employed semi-defined medium without added $\mathrm{CaCl}_{2}$ and was carried out at a constant pH 6.5 in a Bio-Flo chemostat of $325 \mathrm{ml}$ capacity (model C30, New Brunswick Scientific) with $25 \mathrm{~mm}$-glucose as the limiting nutrient. All media used in continuous culture were filter sterilized irrespective of whether or not they contained Tween 80 $\left(0.5 \mu 1 \mathrm{ml}^{-1}\right)$ (Jacques et al., 1979).

Assay of enzyme activities and analysis of fatty acids. Cell-associated and extracellular glycosyltransferase activities (Jacques, 1985) and the fatty acid constituents of the membrane lipids (Markevics \& Jacques, 1985) were measured as previously described. One unit of enzyme activity (U) was defined as the amount of glucosyltransferase or fructosyltransferase that catalysed the incorporation of $1 \mu \mathrm{mol}$ of the glucose or the fructose moiety of sucrose, respectively, into $75 \%(\mathrm{v} / \mathrm{v})$ ethanol-insoluble polysaccharide $\mathrm{min}^{-1}$.

Analysis of extracellular protein components. Culture fluids obtained from batch cultures by centrifugation $\left(10000 \mathrm{~g}, 4^{\circ} \mathrm{C}, 10 \mathrm{~min}\right)$, were either unconcentrated or concentrated fivefold at $4{ }^{\circ} \mathrm{C}$ by dialysis against Aquacide III (Calbiochem-Behring). No significant loss of GTF $_{e}$ or extracellular fructosyltransferase $\left(\mathrm{FTF}_{\mathrm{e}}\right.$ ) activity was observed following the concentration step. SDS-PAGE slab gel electrophoresis was carried out in the buffer system devised by Laemmli (1970) as described by Russell (1976) using $9 \%$ (w/v) acrylamide in the separating gel and a constant voltage of $60 \mathrm{~V}$. Culture supernatant samples $(100 \mu \mathrm{l})$ were solubilized in SDS sample buffer for $2 \mathrm{~h}$ at room temperature and electrophoresis of the samples commenced within $7 \mathrm{~h}$ of inoculating the culture medium. By so doing the breakdown and/or aggregation of the glycosyltransferases was minimized. Molecular mass standards (Pharmacia) were ferritin $(220 \mathrm{kDa})$, phosphorylase $b(94 \mathrm{kDa})$, bovine serum albumin $(67 \mathrm{kDa})$ and ovalbumin (43 kDa). Separated proteins were fixed in methanol/acetic acid/water $(40: 10: 50$, by vol.) and stained with Gradipure electrophoresis gel stain (Gradipore). The limit of detection for this stain is $100 \mathrm{ng}$ protein. Each condition was repeated at least three times to confirm the reproducibility of the results.

Zones of polymer-synthesizing ability in gels were detected using a periodic acid-Schiff stain at room temperature (Konat et al., 1984) after incubation of the gels in sucrose. Following electrophoresis, gels were washed in three changes of $50 \mathrm{~mm}$-Tris/ $\mathrm{HCl}$ buffer $\mathrm{pH} 7.5$ containing $1 \mathrm{mM}-\mathrm{CaCl}_{2}$ and then incubated for $2 \mathrm{~h}$ at $37^{\circ} \mathrm{C}$ in $50 \mathrm{~mm}$-sodium phosphate buffer $\mathrm{pH} 6.5$ containing $1 \%(\mathrm{w} / \mathrm{v})$ sucrose, $1 \mathrm{~mm}-\mathrm{CaCl}_{2} 20 \mu \mathrm{M}$-dextran $\mathrm{T} 10$ (Sigma) plus $0.01 \%(w / v)$ thiomersal (BDH) and 1\% (v/v) Triton X-100 (Sigma) (Russell, 1979a).

The protein profiles of the concentrated samples were more readily quantified. This was done by scanning at $590 \mathrm{~nm}$ with a Gelman ACT scanning microdensitometer attached to a digital integrator.

Analyses of data. All data points represent results from individual experiments unless otherwise indicated. All continuous culture experiments were repeated at least once.

In batch culture, the specific rate of product formation, $q_{p}$, is given by:

$$
q_{\mathrm{p}}=\frac{\left(p-p_{0}\right) \mu}{X_{0}\left(\mathrm{e} u t_{1}-1\right)}
$$

where $p$ is the final product concentration; $p_{0}$ is the initial product concentration; $X_{0}$ is the initial number of bacteria inoculated into the growth vessel; $\mu$ is the specific growth rate and $t_{1}$ is the time interval between measuring $p_{0}$ and $p$ (Pirt, 1975). This equation can be directly applied to $\mathrm{GTF}_{\mathrm{e}}$ and $\mathrm{FTF}_{\mathrm{m}}$ production where the enzymes accumulate in proportion to cell mass (Wittenberger et al., 1978; Jacques \& Wittenberger, 1981). When applied to cell-associated constituents, such as $\mathrm{FTF}_{\mathrm{m}}$ expression or $\mathrm{C}_{18: 1}$ incorporation, $q_{\mathrm{p}}$ gives the minimum rate of synthesis of that constituent that is required to maintain the final product concentration. No estimate of a more rapid turnover can be made.

In the chemostat, changing from one condition to another results initially in non-steady-state conditions for which it can be shown that:

$$
q_{\mathrm{p}}=\frac{D\left(p-\frac{p_{0}}{\mathrm{e}^{D t_{1}}}\right) \mathrm{e}^{D_{t_{1}}}}{\left(\mathrm{e}^{D t_{1}}-1\right)}
$$

where $q_{\mathrm{p}}, p_{0}, p$ and $t_{1}$ are as defined above and $D$ is the dilution rate. 
For equation 2 , as $t_{1} \rightarrow \infty, q_{\mathrm{p}} \rightarrow D p$. For the purpose of this paper, it was assumed that $t_{1} \rightarrow \infty$ after cultures were allowed to equilibrate for seven mean generation times (five volume changes) after changing from one $D$ to another (Jacques et al., 1979). Following the addition of Tween 80 to a culture growing at $D=0.05 \mathrm{~h}^{-1}, \mathrm{C}_{18: 1}$ began to accumulate in the cells after $18 \mathrm{~h}$ at the rate equivalent to the final steady-state rate. This gave rise to a slow but steady increase in the amount of $\mathrm{C}_{18: 1}$ in the membrane lipids until the maximum was achieved some $100 \mathrm{~h}$ after the addition of Tween 80 to the medium. The result implied that at $D=0.05 \mathrm{~h}^{-1}$ the rate of $\mathrm{C}_{18: 1}$ incorporation - given by $0.05 \times\left[\mathrm{C}_{18: 1}\right]$ at steady state - was most likely the maximum rate of incorporation of the fatty acid into the membrane lipids. Whether this was true for each $D$ studied was not determined.

\section{RESULTS}

Effect of the dilution rate on membrane fatty acid composition, $F T F_{m}$ activity and $G T F_{e}$ production

As the dilution rate, $D$, was increased from $0.05 \mathrm{~h}^{-1}$ to $0.8 \mathrm{~h}^{-1}$, the degree of unsaturation of the membrane lipids increased. Octadecenoic and eicosenoic acid $\left(C_{20: 1}\right)$ levels rose essentially at the expense of tetradecanoic $\left(\mathrm{C}_{14: 0}\right)$ and hexadecanoic $\left(\mathrm{C}_{16: 0}\right)$ acids (Table 1).

When cells were grown in the presence of Tween 80 , the oleic acid residue of the surfactant appeared to be incorporated into the cells (Jacques et al., 1985). This resulted in an increase in the amount of octadecenoic acid in the membrane lipids and a significant rise in the unsaturated to saturated fatty acid $(\mathrm{U} / \mathrm{S})$ ratio for each $D$ (Table 1$)$.

In the absence of Tween 80 , the amount of $\mathrm{GTF}_{\mathrm{e}}$ and $\mathrm{FTF}_{\mathrm{m}}$ activity increased with increasing $D$. There was, however, no simple (linear) relation between either of these two enzyme activities and $D$, or between the expression of either enzyme and the amount of octadecenoic acid in the membrane. This conclusion was confirmed by growth in the presence of Tween 80 . Although the levels of both enzymes increased when grown in the presence of the surfactant, the condition giving rise to the highest incorporation of octadecenoic acid $\left(D=0 \cdot 1 \mathrm{~h}^{-1}\right)$ did not maximize the degree of expression of either $\mathrm{FTF}_{\mathrm{m}}$ or $\mathrm{GTF}_{\mathrm{e}}$ activity (Table 1).

\section{Dependence of $F T F_{m}$ production on the rate of octadecenoic acid incorporation into the membrane lipids}

Although the degree of $\mathrm{FTF}_{\mathrm{m}}$ expression was not dependent upon the absolute amount of octadecenoic acid present in the cells for any given $D$, the rate of $\mathrm{FTF}_{\mathrm{m}}$ expression was directly related to the minimum rate of $\mathrm{C}_{18: 1}$ accumulation in the cell membrane, irrespective of the presence or absence of Tween 80 in the growth medium (Fig. 1 $a$ ). The data were consistent with

Table 1. Dilution-rate-dependent alterations in the membrane fatty acids and $G T F_{\mathrm{e}}$ and $F T F_{\mathrm{m}}$ expression in $S$. salivarius in the presence or absence of Tween 80

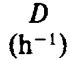

No added Tween 80

0.05

$0 \cdot 1$

$0 \cdot 2$

$0 \cdot 4$

0.6

0.8

+ Tween $80^{*}$

0.05

$0 \cdot 1$

0.2

0.4

0.6

0.8

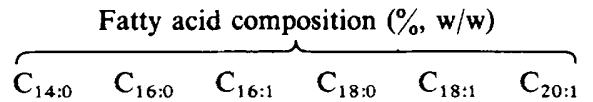

GTF $_{\text {e }}$ [mU (mg dry $w t)^{-1}$ ]

FTF $_{\text {m }}$ [mU (mg dry $w t)^{-1}$ ]

U/S ratio

$\begin{array}{rr}17 \cdot 7 & 51 \cdot 4 \\ 20 \cdot 9 & 49 \cdot 8 \\ 15 \cdot 2 & 44 \cdot 5 \\ 10 \cdot 0 & 45 \cdot 7 \\ 4 \cdot 1 & 45 \cdot 3 \\ 1 \cdot 4 & 39 \cdot 7 \\ & \\ 5 \cdot 9 & 23 \cdot 4 \\ 6 \cdot 6 & 18 \cdot 7 \\ 7 \cdot 2 & 25 \cdot 1 \\ 5 \cdot 3 & 24 \cdot 8 \\ 3 \cdot 1 & 33 \cdot 7 \\ 2.9 & 33 \cdot 5\end{array}$

$\begin{array}{rrrr}10.6 & 2.8 & 17.0 & 0.6 \\ 10.9 & 2.3 & 15.2 & 0.9 \\ 13.8 & 4.8 & 20.4 & 1.2 \\ 9.9 & 3.7 & 25.8 & 5.0 \\ 10.1 & 5.2 & 29.4 & 6.0 \\ 9.0 & 7.6 & 31.9 & 10.5 \\ & & & \\ 8.0 & 5.4 & 54.1 & 3.2 \\ 8.1 & 4.3 & 60.2 & 2.2 \\ 9.1 & 3.4 & 49.7 & 5.4 \\ 9.0 & 4.1 & 47.4 & 9.3 \\ 9.3 & 3.8 & 42.3 & 7.9 \\ 9.5 & 3.3 & 42.8 & 8.2 \\ & & & \end{array}$

4
5
6
13
21
38

674
495
562
1180
477
644




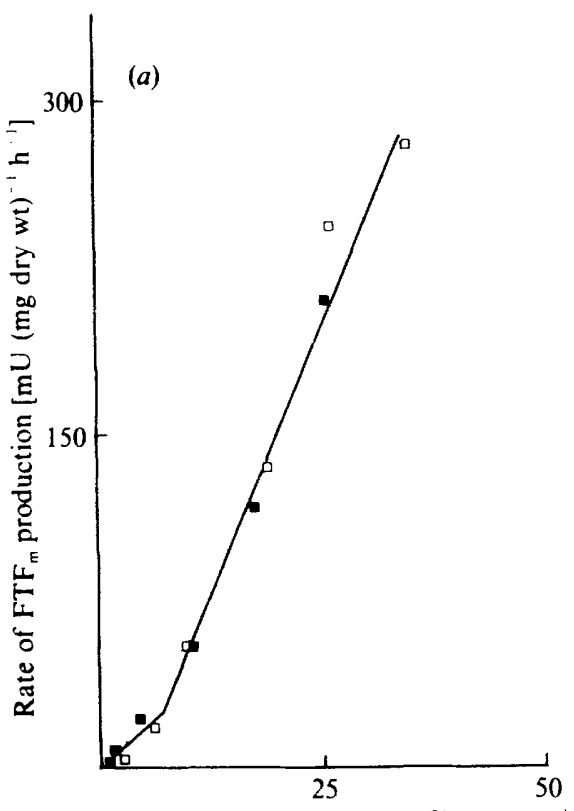

Rate of $\mathrm{C}_{18,1}$ incorporation $\left(\%, \mathrm{w} / \mathrm{w} \mathrm{h}^{-1}\right)$

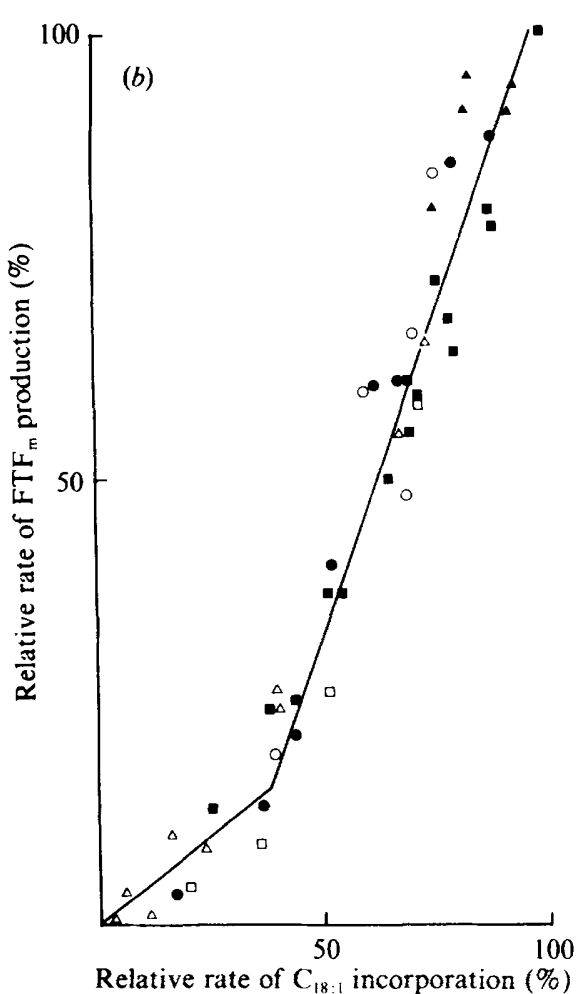

Relative rate of $\mathrm{C}_{18 \cdot 1}$ incorporation (\%)

Fig. 1. (a) Relation between the rate of $F F_{m}$ expression and the rate of $C_{18: 1}$ incorporation into the membrane lipids of cells grown in continuous culture in the absence ( $\square$ ) or in the presence ( $\square$ ) of Tween $80\left(0.5 \mu \mathrm{l} \mathrm{ml}^{-1}\right)$. (b) Relation between rate of $\mathrm{FTF}_{\mathrm{m}}$ expression and rate of $\mathrm{C}_{18: 1}$ incorporation into the membrane lipids for cells grown in batch culture in the presence of $n$-alkanols or in continuous culture in the presence or absence of Tween 80 . Data are normalized with respect to the appropriate batch culture grown in the absence of added $n$-alkanol $(100 \%)$ or in continuous culture to $D=0.8 \mathrm{~h}^{-1}$ in the absence of added Tween $80(100 \%) . \triangle$, Cells grown in continuous culture; cells grown in the

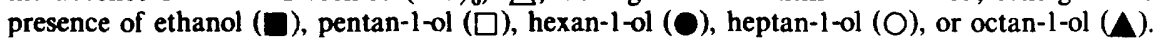

a biphasic linear relation between the two variables, a more rapid expression of $\mathrm{FTF}_{\mathrm{m}}$ activity occurring once the rate of $\mathrm{C}_{18: 1}$ accumulation exceeded $6-8 \%, \mathrm{w} / \mathrm{w} \mathrm{h}^{-1}$.

When $S$. salivarius was grown in batch culture in the presence of a series of n-alkanols, FTF $_{m}$ expression decreased with increasing concentrations of each alkanol studied (Markevics et al., 1987). Normalized data from each of the series of n-alkanols plotted in the same biphasic fashion, confirming the relation between the rate of $\mathrm{FTF}_{\mathrm{m}}$ expression and the rate of $\mathrm{C}_{18: 1}$ incorporation into the membrane lipids (Fig. $1 b$ ).

\section{Stimulation of $G T F_{\text {e }}$ production}

The rate of GTF $_{e}$ production increased in a non-linear manner with respect to the rate of $C_{18: 1}$ incorporation into the membrane lipids when cells were grown in continuous culture in the absence of added Tween 80 . The rate of $\mathrm{GTF}_{\mathrm{e}}$ production was exponential, but biphasic when plotted against the rate of $\mathrm{C}_{18: 1}$ incorporation (Fig. 2).

In the presence of Tween 80 , no relation between the rate of $\mathrm{GTF}_{\mathrm{e}}$ production and rate of $C_{18: 1}$ incorporation was apparent (data not shown). However, analysis of the data for each $D$ indicated an exponential relation between the increased rate of $\mathrm{GTF}_{\mathrm{e}}$ production following the addition of Tween 80 to the culture medium and the concomitant net increase in the rate of $C_{18: 1}$ incorporation (Fig. 3). These observations on chemostat-grown organisms emphasized that $D$ 


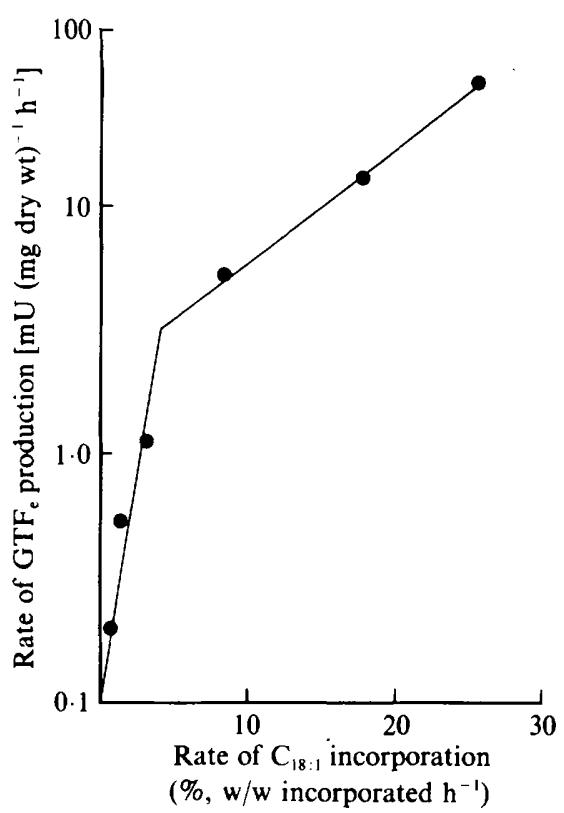

Fig. 2

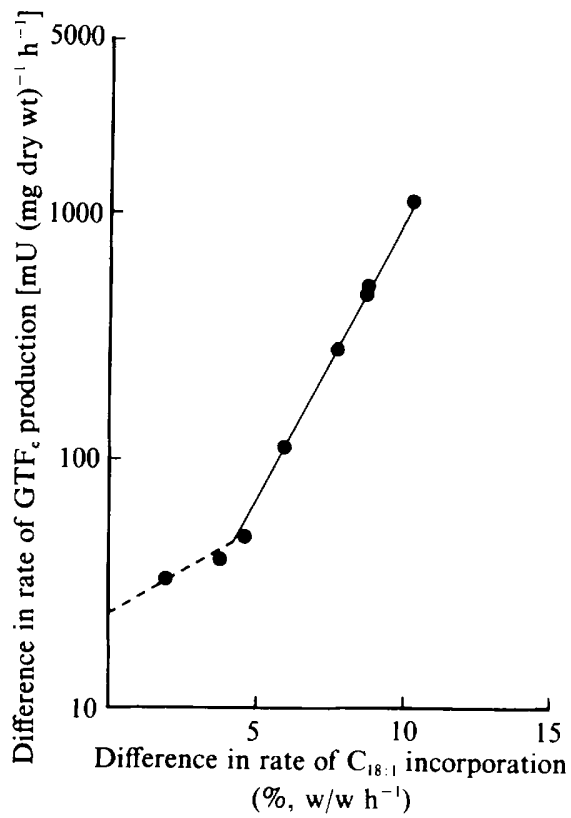

Fig. 3

Fig. 2. Relation between the rate of $\mathrm{GTF}_{\mathrm{e}}$ production and rate of $\mathrm{C}_{18: 1}$ incorporation in continuous culture in the absence of added Tween 80 .

Fig. 3. Relation between the increase in the rate of $\mathrm{GTF}_{\mathrm{e}}$ production and the increase in rate of $\mathrm{C}_{18: 1}$ incorporation for each $D$ following the addition of Tween $80\left(0.5 \mu \mathrm{ml}^{-1}\right)$ to the continuous culture medium. Values were calculated by subtracting the rates obtained in the absence of Tween 80 from those obtained in the presence of Tween 80 for each growth condition $(D)$.

and hence growth rate had an underlying effect on the expression of $\mathrm{GTF}_{\mathrm{e}}$ activity independent of the effect of Tween 80 and unlike that for the expression of $\mathrm{FTF}_{\mathrm{m}}$ activity. Removal of Tween 80 from the inflowing medium resulted in a complete reversal both in the rate of $\mathrm{GTF}_{\mathrm{e}}$ production and the rate of $\mathrm{C}_{18: 1}$ incorporation into the membrane lipids (data not shown).

When batch cultures were grown in the presence of a series of n-alkanols, the rate of GTF $_{e}$ production decreased with decreasing rate of $\mathrm{C}_{18: 1}$ incorporation until a minimum was reached after which the rate of $G_{T F}$ production increased. High concentrations of hexan-1-ol stimulated $\mathrm{GTF}_{\mathrm{e}}$ production in this manner more than any other n-alkanol tested (Markevics $e t$ al., 1987). Despite this, a single ' $U$ '-shaped curve for the relative rate of $G_{T F}$ production versus the relative rate of $C_{18: 1}$ incorporation could be drawn. All data points plotted about this curve regardless of the chain length of the n-alkanol studied (Fig. 4). The data obtained from continuous culture in the absence of Tween 80 (Fig. 2) plotted along the right hand branch of the ' $U$ '-shaped curve shown in Fig. 4. After the minimum was reached, the continuous culture data approached zero at low relative rates of $\mathrm{C}_{18: 1}$ incorporation.

\section{Effect of Tween 80 on the extracellular protein profile of $S$. salivarius}

The addition of $0.05 \mu 1$ Tween $80 \mathrm{ml}^{-1}$ to batch cultures of $S$. salivarius resulted in major increases in the two protein bands of 145 and $160 \mathrm{kDa}$ that possessed the majority of the $\mathrm{GTF}_{\mathrm{e}}$ activity. Smaller increases were noted within the intervening region above $90 \mathrm{kDa}$ where some glycosyltransferase activity was detected using the periodic acid-Schiff stain (data not shown). The existence of multiple activity bands is characteristic of the instability of these enzymes (Russell, $1979 \mathrm{~b}$ ). In fact, storage of the culture fluids for $7 \mathrm{~d}$ at $4{ }^{\circ} \mathrm{C}$ led to significant degradation of the two major protein bands and an increase in activity within the intervening region (data not shown). The data obtained from these electrophoretic protein profiles suggested that 


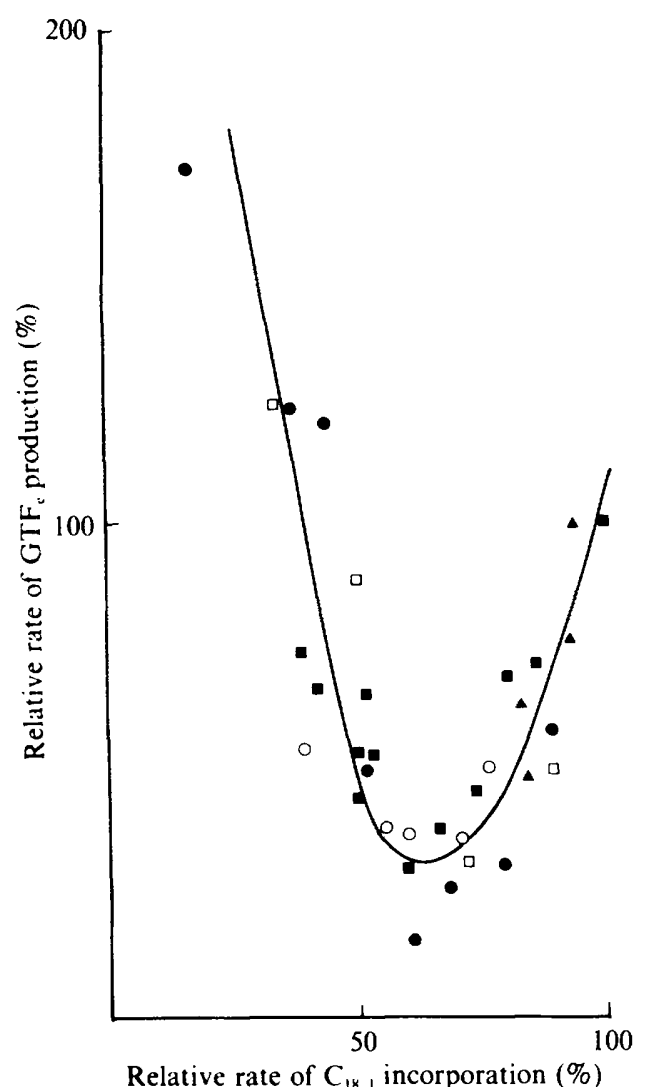

Fig. 4. Increase in the rate of $\mathrm{GTF}_{\mathrm{e}}$ production at low rates of $\mathrm{C}_{18: 1}$ incorporation in batch cultures grown in the presence of $n$-alkanols. Data are normalized with respect to the appropriate batch culture grown in the absence of added n-alkanol $(100 \%)$. Cells grown in the presence of ethanol $(\square)$, pentan-1ol $(\square)$, hexan-1-ol (O), heptan-1-ol (O) or octan-1-ol (A)

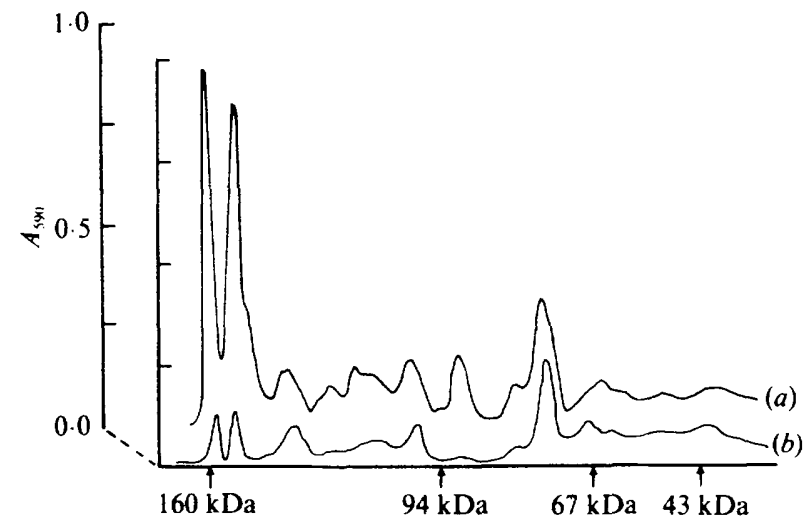

Fig. 5. Microdensitometry scans following SDS-PAGE of concentrated culture fluid obtained from cells grown in batch culture in the presence $(a)$ and absence $(b)$ of $0.05 \mu l$ Tween $80 \mathrm{ml}^{-1}$. Migration distances for proteins of known molecular mass are also shown. No apparent increase in any protein band was detected in the region below $43 \mathrm{kDa}$ when $0.05 \mu \mathrm{l}$ Tween $80 \mathrm{ml}^{-1}$ was added to the culture fluid. 
Tween 80 uniquely stimulated $\mathrm{GTF}_{\mathrm{e}}$ production as no concomitant net increase in other extracellular proteins was observed (Fig. 5). As further evidence for this conclusion, the preparations from cultures grown in the presence of Tween 80 and analysed by electrophoresis (Fig. 5) possessed 7-5-fold greater $\mathrm{GTF}_{\mathrm{e}}$ activities compared with those grown in the absence of the surfactant. The same preparations showed no significant increase in FTF $_{\mathrm{e}}$ activity. Similar electrophoretic protein profiles with unique stimulation of the two major $\mathrm{GTF}_{\mathrm{e}}$ protein bands have also been obtained by growth in the presence of $12.5 \mathrm{~mm}$-hexan-1-ol (data not shown).

\section{DISCUSSION}

Analyses of the data obtained by modulating the fatty acid profile of the cell membrane by the three separate procedures of altered growth rate, addition of Tween 80 or the addition of a series of $n$-alkanols gave rise to the same biphasic linear relation between the rate of $\mathrm{FTF}_{\mathrm{m}}$ expression and the rate of $\mathrm{C}_{18: 1}$ incorporation into the membrane. This biphasic relation, in fact, existed for both $\mathrm{FTF}_{\mathrm{m}}$ and $\mathrm{GTF}_{\mathrm{e}}$ expression in the presence or absence of Tween 80 once the rate of $\mathrm{C}_{18: 1}$ incorporation exceeded $8 \%, \mathrm{w} / \mathrm{w} \mathrm{h}^{-1}$. In the absence of surfactant, this change occurred at a $\mathrm{U} / \mathrm{S}$ ratio of about 0.65 , and has been observed in other studies where $\mathrm{K}^{+}$concentration affects $\mathrm{GTF}_{\mathrm{e}}$ expression (L. J. Pitty \& N. A. Jacques, unpublished observations). Whether alterations in membrane structure such as changes in the lipid species are occurring at this point is not known. The data for FTF $_{m}$ expression, however, were consistent with one of two alternative models for the mode of expression of $\mathrm{FTF}_{\mathrm{m}}$ in $S$. salivarius. Either $\mathrm{FTF}_{\mathrm{m}}$ could not be inserted into the membrane without concomitant net synthesis of lipids containing $C_{18: 1}$ fatty acids (Nesmeyanova, 1982), or $\mathrm{FTF}_{\mathrm{m}}$ may need a covalently linked lipid moiety containing the $\mathrm{C}_{18: 1}$ fatty acid or simply the $\mathrm{C}_{18: 1}$ fatty acid covalently linked to the protein itself for activity to be expressed on the surface of the cell (Neilsen \& Lampen, 1982; Pugsley \& Schwartz, 1985; Fujiyama \& Tamanoi, 1986; Low et al., 1986; Wold, 1986).

The situation with $\mathrm{GTF}_{\mathrm{e}}$ production was far more complex. $\mathrm{GTF}_{\mathrm{e}}$ synthesis and secretion in the presence or absence of Tween 80 was not simply (linearly) related to the rate of $C_{18: 1}$ incorporation into the plasma membrane as was the rate of $\mathrm{FTF}_{\mathrm{m}}$ expression. This fact was exemplified by the observation that a similar rate of $\mathrm{GTF}_{\mathrm{e}}$ expression occurred at $D=0.8 \mathrm{~h}^{-1}$ in the absence of Tween 80 and at $D=0.05 \mathrm{~h}^{-1}$ in the presence of Tween 80 . The rate of $C_{18: 1}$ incorporation, however, was ninefold less in the latter case. This observation emphasized the underlying effect that growth rate in continuous culture had on the expression of $\mathrm{GTF}_{\mathrm{e}}$ activity before any superimposed effect of the surfactant. Despite this, the addition of Tween 80 to the medium resulted in significant increases in the U/S ratio for each $D$, such that at low $D$ more than $30 \%$ of the lipid species would have to contain di-unsaturated fatty acids. Such changes are consistent with the formation of the inverted hexagonol $\left(\mathrm{H}_{\mathrm{II}}\right)$ phase within the plasma membrane, for a number of phospho- and glycolipids are capable of forming these phases as the degree of unsaturation increases (Cullis \& de Kruijff, 1979; Israelachvili et al., 1980; Brenner, 1984, Gruner et al., 1985). A role for non-bilayer phases, including the formation of the $\mathrm{H}_{\mathrm{II}}$ phase, has been suggested in various models for the general translocation of proteins across membranes (Di Rienzo \& Inouye, 1979; Nesmeyanova, 1982; Pugsley \& Schwartz, 1985; Martinek et al., 1986). However, should such phases play a role in the Tween 80 stimulation of $\mathrm{GTF}_{\mathrm{e}}$ production, that role would have to be unique to this enzyme(s) as other extracellular proteins of $S$. salivarius are not stimulated in the same manner. Furthermore, with hexan-1-ol (Markevics et al., 1987) and octyl $\beta$-D-glucopyranoside (Jacques, 1985) such a model is far more difficult to perceive since the degree of unsaturation of the membrane decreases with increasing concentrations of these amphiphiles (Markevics et al., 1987). However, theoretical considerations suggest that hexan-1-ol, at least, may self-associate and form alkanol-rich domains or nonbilayer clusters within the membrane at concentrations which lead to a stimulation of $\mathrm{GTF}_{\mathrm{e}}$ synthesis and secretion (Brasseur et al., 1985).

Irrespective of whether or not the various methods previously reported for the enhancement of $\mathrm{GTF}_{e}$ underlie a unified mechanism for the control of the synthesis and secretion of the enzyme(s) by $S$. salivarius, the present study indicates that with decreasing $D$ (and therefore with 
increasing generation times), the bacterium readily adapts its membrane to a more ordered state consistent with a lowering of the phase transition temperature (Table 1). This observation may have a number of important ramifications with respect to streptococcal physiology not the least of which is the one seen here - that of the apparent control over the expression of the two major glycosyltransferase enzyme systems used for polymerizing sucrose. Such changes in the membranes may represent a simple feed-back control to prevent wastage in the formation of unnecessary enzymes under unfavourable (non-ingestion of food) conditions in the natural oral environment. This notion is supported by the results obtained previously with the addition of Tween 80 or the changing of $\mathrm{K}^{+}$concentration, both of which may play a role in vivo in man in controlling glycosyltransferase expression with food intake since Tween 80 is listed as a surfactant that can safely be used in food processing (Fisher \& Parker, 1985) while the $\mathrm{K}^{+}$ concentration alters with salivary flow (Shannon et al., 1974).

This work was supported by a Program Grant awarded by the Australian National Health and Medical Research Council.

\section{REFER E NCES}

Brasseur, R., Chatelain, P., Goormaghtigh, E. \& RUYSSChAERT, J.-M. (1985). A semi-empirical conformational analysis of the interaction of $n$-alkanols with dipalmitoylphosphatidylcholine. Biochimica et biophysica acta 814, 227-236.

BRENNER, R. R. (1984). Effect of unsaturated acids on membrane structure and enzyme kinetics. Progress in Lipid Research 23, 69-96.

Cullis, P. R. \& DE KRUIJFF, B. (1979). Lipid polymorphism and the functional roles of lipids in biological membranes. Biochimica et biophysica acta 559, 399-420.

Di Rienzo, J. M. \& Inouye, M. (1979). Lipid fluiditydependent biosynthesis and assembly of outer membrane proteins of $E$. coli. Cell 17, 155-161.

Fisher, L. R. \& PARKer, N. S. (1985). How do food emulsion stabilizers work? CSIRO Food Research Quarterly 45, 33-39.

Funiyama, A. \& Tamanoi, F. (1986). Processing and fatty acid acylation of RAS1 and RAS2 proteins in Saccharomyces cerevisiae. Proceedings of the National Academy of Sciences of the United States of America 83, $1266-1270$.

Gruner, S. M., Cullis, P. R., HoPe, M. J.\& Tilcock, C. P. S. (1985). Lipid polymorphism: the molecular basis of nonbilayer phases. Annual Review of Biophysical Chemistry 14, 211-238.

Israelachvili, J. N., Marcelja, S. \& Horn, R. G. (1980). Physical principles of membrane organization. Quarterly Review of Biophysics 13, 121-200.

JACQUES, N. A. (1983). Membrane perturbation by cerulenin modulates glucosyltransferase secretion and acetate uptake by Streptococcus salivarius. Journal of General Microbiology 129, 3293-3302.

JACQUES, N. A. (1985). Inhibition of the expression of cell-associated fructosyltransferase in Streptococcus salivarius by octyl $\beta$-D-glucopyranoside. Journal of General Microbiology 131, 3243-3250.

JACQUES, N. A. \& WITTENBERGER, C. L. (1981). Inactivation of cell-associated fructosyltransferase in Streptococcus salivarius. Journal of Bacteriology 148, 912-918.

JaCQues, N. A., Hardy, L., KNox, K. W. \& Wicken, A. J. (1979). Effect of growth conditions on the formation of extracellular lipoteichoic acid by Streptococcus mutans BHT. Infection and Immunity 25, 75-84.

Jacques, N. A., Jacques, V. L., Wolf, A. C. \& Wittenberger, C. L. (1985). Does an increase in membrane unsaturated fatty acids account for Tween 80 stimulation of glucosyltransferase secretion by Streptococcus salivarius? Journal of General Microbiology 131, 67-72.

Konat, G., Offner, H. \& Mellah, J. (1984). Improved sensitivity for detection and quantitation of glycoproteins on polyacrylamide gels. Experientia 40, 303-304.

LAEMMLI, U. K. (1970). Cleavage of structural proteins during the assembly of the head of bacteriophage T4. Nature, London 227, 680-685.

Low, M. G., Ferguson, M. A. J., Futerman, A. H. \& Sirman, 1. (1986). Covalently attached phosphatidylinositol as a hydrophobic anchor for membrane proteins. Trends in Biochemical Sciences 11, 212-215.

Markevics, L. J. \& Jacques, N. A. (1985). Enhanced secretion of glucosyltransferase by changes in potassium ion concentrations is accompanied by an altered pattern of membrane fatty acids in Streptococcus salivarius. Journal of Bacteriology 161, 989994.

Markevic,, L. J., KaH, K. K., Rathsam, L., Turner, L. W. \& JacQues, N. A. (1987). Adaptation of the membrane fatty acid composition by growth in the presence of $\mathrm{n}$-alkanols influences glycosyltransferase expression in Streptococcus salivarius. Journal of General Microbiology 133, 1543-1551.

Martinet, K., LeVashov, A. V., Klyachko, N., KhMELNITSKI, Y. L. \& BeRESIN, I. V. (1986). Micellar enzymology. European Journal of Biochemistry 155, 453-468.

NeILSEN, J. B. K. \& LAMPEN, J. O. (1982). Membranebound penicillinase in Gram-positive bacteria. Journal of Biological Chemistry 257, 4490-4495.

Nesmeyanova, M. A. (1982). On the possible participation of acid phospholipids in the translocation of secreted proteins through the bacterial cytoplasmic membrane. FEBS Letters 142, 189-193. 
PIRT, S. J. (1975). Principles of Microbe and Cell Cultivation, p. 160. Melbourne: Blackwell.

Pugsley, A. P. \& SChWARTZ, M. (1985). Export and secretion of proteins by bacteria. FEMS Microbiological Reviews 32, 3-38.

Russell, R. R. B. (1976). Classification of Streptococcus mutans strains by SDS gel electrophoresis. Microbios Letters 2, 55-59.

Russell, R. R. B. (1979a). Use of Triton X100 to overcome the inhibition of fructosyltransferase by SDS. Analytical Biochemistry 97, 173-175.

RUSSELL, R. R. B. $(1979 b)$. Glycosyltransferases of
Streptococcus mutans strain Ingbritt. Microbios 23, $135-146$.

Shannon, I. L., Suddick, R. P. \& Dowd, F. J., JR (1974). Saliva: composition and secretion. Monographs of Oral Science 2, 3-23.

WITtenberger, C. L., Beaman, A. J. \& LeE, L. N. (1978). Tween 80 effect on glucosyltransferase synthesis in Streptococcus salivarius. Journal of Bacteriology 133, 231-239.

WOLD, F. (1986). Fatty acylation of proteins (keep fit with fat?). Trends in Biochemical Sciences 11, 58-59. 